\title{
11 The Case for Workplace Democracy
}

\author{
David Ellerman
}

\section{Introduction}

In this chapter I seek to provide a theoretical defence of workplace democracy that is independent from and outside the lineage of Marxist and communist theory. Common to the council movements, anarcho-syndicalism and many other forms of libertarian socialism was the idea "that workers' self-management was central." 'Yet the idea of workers' control has not been subject to the same theoretical development as Marx's theory, not to mention capitalist economic theory. This chapter aims to contribute at a theoretical level by providing a justification and defence of self-managed workplaces that is independent of the particular historical tradition of the council movements.

There is a clear and definitive case for workplace democracy based on first principles that descends to modern times through the Reformation and Enlightenment in the abolitionist, democratic and feminist movements. By the twentieth century, the arguments had been scattered and lost like the bones of some ancient beast scattered in a desert - partly due to misconceptions, mental blocks and misinterpretations embodied in Marxism, liberalism and economic theory. When one has worked through some of these intellectual roadblocks, then one may be better able to reassemble the case for workplace democracy from well-known first principles developed in the abolitionist, democratic and feminist movements.

\section{The Basic Misconception of Liberalism}

The modern liberal consciousness was formed in the nineteenth century with the abolition of slavery and the triumph of political democracy as the normative ideal in the West. Both changes were interpreted as moving from a coercive system to a system based on consent. Thus "consent" became the root principle of liberalism (always in the European sense of classical liberalism), a principle further exemplified with the post-socialist resurgence of market societies. 
But this "liberal principle of consent" is both a conceptual oversimplification of the issues as well as a historical falsification of the debates. There were always sophisticated arguments for slavery and for non-democratic forms of government based on consent. The advances in anti-slavery arguments and democratic arguments based on the inalienable rights arguments of the Reformation and Enlightenment were made against those liberal defences of slavery and autocracy based on consent. These inalienable rights arguments have been largely lost to modern liberalism (not to mention, neoclassical economics) with its dumbed-down dichotomy of "coercion versus consent." Of course, there were always illiberal defences of slavery and autocracy (e.g. racist arguments or divine-right theories), and those are precisely the ones propped up as strawmen and then batted down by liberal philosophers and intellectual historians as they portray the triumphal march "from Status to Contract."”

\section{Slavery}

Take slavery. The contractual arguments for slavery go back even to antiquity. In Justinian's codification of Roman law, each of the three legal means of becoming a slave had an incidence of contract. One means was an explicit contract to sell one's labour services all at once, the self-sale contract. Another means was the practice of allowing prisoners of war to plea bargain a lifetime of labour instead of being executed. Finally, those who were born slaves received food, clothing and shelter from their masters and they could (by manumission) pay off this liability inherited from their mothers' contractual condition, or they could continue the arrangement for another generation.

Frank Knight pointed out that the foundations of classical liberalism were laid well before Adam Smith: "Interestingly enough, the political and legal theory had been stated in a series of classics, well in advance of the formulation of the economic theory by Smith. The leading names are, of course, Locke, Montesquieu, and Blackstone."3 All three of these classical liberal writers accepted a voluntary slavery contract as long as there was some semblance of rights on both sides, for example, so that a master may not arbitrarily kill his slave. Here are the three pertinent quotations:

For, if once Compact enter between them, and make an agreement for a limited Power on the one side, and Obedience on the other, the State of War and Slavery ceases, as long as the Compact endures ... I confess, we find among the Jews, as well as other Nations, that Men did sell themselves; but, 'tis plain, this was only to Drudgery, not to Slavery. For, it is evident, the Person sold was not under an Absolute, Arbitrary, Despotical Power. ${ }^{4}$

This is the true and rational origin of that mild law of slavery which obtains in some countries; and mild it ought to be, as founded on the 


\section{2}

free choice a man makes of a master, for his own benefit; which forms a mutual convention between two parties. ${ }^{5}$

Yet, with regard to any right which the master may have lawfully acquired to the perpetual service of John or Thomas, this will remain exactly in the same state as before: for this is no more than the same state of subjection for life, which every apprentice submits to for the space of seven years, or sometimes for a longer term. ${ }^{6}$

In the American debates over slavery, people like Reverend Samuel Seabury gave perfectly liberal contractarian defences of slavery - while George Fitzhugh and a host of others gave illiberal and racist arguments. ${ }^{7}$ The reader is invited to see which strawmen are propped up and batted down in the standard histories of the slavery debates. For instance, modern liberal scholars of pro-slavery thought can't seem to find Seabury or any of the earlier contractarian defences. Eric McKitrick collects essays of 15 pro-slavery writers; ${ }^{8}$ Harvard University's current president, Drew Gilpin Faust, ${ }^{9}$ collects essays from seven pro-slavery writers; and Paul Finkelman collects 17 excerpts from pro-slavery writings. ${ }^{10}$ But none of them include a single writer who argues to allow slavery on a contractual basis such as Seabury - not to mention Grotius, Pufendorf, Locke, Blackstone, Montesquieu and a host of Scholastics such as Jean Gerson, Luis de Molina and Francisco Suarez. ${ }^{11}$

As was pointed out by some pro-slavery writers, the essential economic difference between the slave and the hireling is the amount of labour purchased at once:

With us this property does not consist in human "flesh" ... Our property in man is a right and a title to human labor. And where is it that this right and title does not exist on the part of those who have the money to buy it? The only difference in any two cases is the tenure ... Our slave-property lies only incidentally in the person of the slave but essentially in his labor. Who buys a slave except he has work for him? His person is held as the only sure means of obtaining his labor. The proprietorship of his person extends only so far as the derivation of a fair amount of labor. The value of the slave is determined by the sort and amount of labor he is capable of and it is according to these that he is bought and sold; and it is undeniable that these are the same conditions which determined the hireling's wages. ${ }^{12}$

Or as James Mill, the utilitarian liberal and father of John Stuart Mill, pointed out:

The labourer, who receives wages sells his labour for a day, a week, a month, or a year, as the case may be. The manufacturer, who pays these wages, buys the labour, for the day, the year, or whatever period 
it may be. He is equally therefore the owner of the labour, with the manufacturer who operates with slaves. The only difference is, in the mode of purchasing. The owner of the slave purchases, at once, the whole of the labour, which the man can ever perform: he, who pays wages, purchases only so much of a man's labour as he can perform in a day, or any other stipulated time. ${ }^{13}$

If a contractual relationship to buy "the whole of the labour, which the man can ever perform" was morally wrong in spite of being voluntary, then the current economic system based on the voluntary contract for the shorter-term purchase of labour "for the day, the year, or whatever period it may be" might be put in moral jeopardy. Hence responsible intellectual historians and liberal scholars just cannot go there.

Today, the reigning social model finds its "scientific" expression in the neoclassical model of competitive capitalism which not only allows, but requires for efficiency, complete future markets in all goods and services including labour. Although self-sale contracts were outlawed when slavery was abolished, the shining exemplar of liberal thought (the neoclassical economic model) requires that such lifetime labour contracts be re-allowed in order to get the basic efficiency results.

Now it is time to state the conditions under which private property and free contract will lead to an optimal allocation of resources ... The institution of private property and free contract as we know it is modified to permit individuals to sell or mortgage their persons in return for present and/or future benefits. ${ }^{14}$

To place emphasis on the libertarian logic of freedom, the late Harvard philosopher, Robert Nozick, has argued that a free system would allow an individual "to sell himself into slavery." As if to emphasise the modern learned ignorance of Enlightenment inalienable rights doctrine, Nozick even reinterprets an "inalienable" right as a right that one may not give up without consent - which just identifies "inalienable rights" with "rights" as opposed to privileges. Nozick thus has no notion whatever of "inalienable rights" in the original sense of a right that one may not give up even with consent (e.g. due to the inherent invalidity of the contract to alienate any rights one has qua person).

\section{Non-democratic Government}

The contractual arguments for allowing non-democratic government also go back to antiquity and continue down to Nozick. Any rulership that existed as a settled condition was interpreted as based on an implicit contract or covenant with the people - settled by the prescription of time. In the Institutes of Justinian, we find that the Roman people have by the 


\section{David Ellerman}

lex regia enacted the imperium of the ruler. The German legal scholar, Otto Gierke, finds that by the late Middle Ages, it was propounded as a philosophical axiom that rulership was based on a voluntary contractual alienation of rights from the ruled to the ruler, the contract of subjection or pactum subjectionis. ${ }^{15}$ Or as medieval scholar Brian Tierney pointed out: "The idea that licit rulership was conferred by consent of the community to be ruled was fairly commonplace at the beginning of the fourteenth century." 16 Surely the best-known version of this doctrine was Thomas Hobbes' theory of contractual autocracy. To avoid the war of all against all that would make life "nasty, brutish, and short," each along with the other would alienate the right of self-determination to the sovereign. This liberal tradition of non-democratic government based on the "consent of the governed" continues down to Harvard's poster-child for free-market principles whose libertarian vision of a free system would allow the pactum subjectionis where individuals contract away their governance rights to a "dominant protective association." 17

This completes the summary of the basic misconception of liberalism, that the abolition of slavery and the triumph of political democracy represented a decision for consent over coercion. The older non-trivial debate, lost to modern liberalism, was not between consent and coercion but between two opposite forms of consensual arrangements. It was between a Hobbesian contract to alienate the rights of self-determination and a democratic constitution to secure those rights which are only delegated to the governors/managers.

During the Middle Ages the question was much debated whether the lex regia effected an absolute alienation (translatio) of the legislative power to the Emperor, or was a revocable delegation (cessio). The champions of popular sovereignty at the end of this period, like Marsiglio of Padua in his Defensor Pacis, took the latter view. ${ }^{18}$

The non-trivial argument for democracy was not the usual liberal stance in favour of consent instead of coercion, but the inalienable rights argument against the voluntary alienation contract and in favour of the voluntary delegation contract.

There is, at least, one right that cannot be ceded or abandoned: the right to personality. Arguing upon this principle the most influential writers on politics in the seventeenth century rejected the conclusions drawn by Hobbes. They charged the great logician with a contradiction in terms ... There is no pactum subjectionis, no act of submission by which man can give up the state of free agent and enslave himself. For by such an act of renunciation he would give up that very character which constitutes his nature and essence: he would lose his humanity. ${ }^{19}$ 
It means, as the examples of modern economics and philosophical libertarianism illustrate, that the non-trivial inalienable rights arguments against such alienation contracts have been "forgotten." And for good reason. As Philmore put it, perhaps ironically:

Contractual slavery and constitutional non-democratic government are, respectively, the individual and social extensions of the employeremployee contract. Any thorough and decisive critique of voluntary slavery or constitutional non-democratic government would carry over to the employment contract - which is the voluntary contractual basis for the free market free enterprise system. ${ }^{20}$

Thus the "problem" is that when the old inalienable rights arguments are understood in clear and modern terms, then it is quickly seen that the arguments cut far deeper than just ruling out buying other people and political autocracy - they also rule out the renting of persons and the workplace pactum subjectionis of the employment contract.

\section{A Linguistic Glass Wall in Capitalist Talk}

Let us pause to consider an amusing invisible barrier in "capitalist talk." Suppose a person lived in the middle of a slave society (e.g. the antebellum American South). Surely when asked if they knew of a society based on owning other human beings, they would recognise their own society as an example. Now consider present-day society and consider the following experiment the author has conducted with economics students.

First the students are told about the system of chattel slavery where workers are bought and sold as moveable property. But just as a house or a car can be bought and sold, so one can also rent a house or car. Now instead of buying workers as in a slavery system, suppose we consider a system of renting workers. The students are asked if anyone knows an economic system based on the renting of workers. There is usually a puzzled silence. A Black student might point out that during slack times in the period of slavery, plantation slaves were rented out to work as stevedores, as hands in factories (e.g. turpentine or sugar mills) or as common labourers. The professor agrees, but asks again for an example of a whole economic system based on renting people. After another pause, some students offer, "well, what about feudalism?" The professor responds that feudalism might be seen as based on the voluntary homage contract that permanently attached the serf to the manor and was not a temporary rental contract. Thus we still need an example of a system of renting people. After more embarrassed silence and shuffling feet, finally a student, by the process of elimination if by no other logic, offers: "Well, isn't that sort of like what we have now?"21

Yes, except that we use the word "hiring" or some other euphemism ("employing" or "giving a job") instead of "renting" when people are 
rented in an employment contract. Economists can sometimes be quite frank about the matter. As the late dean of neoclassical economics, Paul Samuelson, put it: "Since slavery was abolished, human earning power is forbidden by law to be capitalised. A man is not even free to sell himself: he must rent himself at a wage." 22 Or as other neoclassicals put it:

To clarify our discussion of capital we ... emphasize two crucial distinctions: between stocks and flows, and between rental payments and asset prices. We begin with the example of labour input ... The labour market trades a commodity called "hours of labour services." The corresponding price is the hourly wage rate. Rather loosely, we sometimes call this the "price of labour." Strictly speaking, the hourly wage is the rental payment that firms pay to hire an hour of labour. There is no asset price for the durable physical asset called a "worker" because modern societies do not allow slavery, the institution by which firms actually own workers. ${ }^{23}$

Hiring and renting are used interchangeably when referring to cars (e.g. "hire-car" in the UK instead of "rental-car" in the US), but not for people. Learning this unwritten rule is part of being socialised into a society based on renting human beings. Try it on your friends.

\section{The "R"-Word That Cannot Be Spoken in Economics}

The "science" of economics has even stronger unwritten rules as to what words and concepts can be used. Certain facts, known to all, are quite unmentionable in this "science." For instance, we all know that only people can be blamed or held responsible for anything. We all might occasionally indulge animistic metaphors about "things" being blamed for some outcome, but we are well aware of the metaphor. We know, for example, that when a crime is committed, the responsibility for the crime must be imputed back through the tools or instruments to the human users. When we do not blame the knife or gun for a crime, we do not think for a moment that the instrument was therefore of no "help" to the perpetrator in the commission of the crime (and thus some crimes and many accidents might be prevented if such tools were scarcer). Of course, such instruments have some efficacy in crimes; otherwise they would not be used. But we have no trouble differentiating that efficacy from responsibility for the crime. No trouble, that is, unless one is a professional economist who must, in the interests of science, "overlook" what everyone knows.

This simple and definitive differentiation of human actions from the services of things on the basis of the "R"-word, "responsibility," has been lost to economics for the whole twentieth century. In economics, human actions and the services of things are seen alike as having a causal efficacy called "productivity" and they are represented symmetrically as input services 
in "production functions." Economists flip-flop between two symmetrical pictures of the production process. When feeling scientific, economists adopt an engineering mentality and a passive voice; the inputs are technologically transformed into the outputs. When economists wax poetical, then all the inputs (such as land, labour and capital) co-operate together to produce the product. "Together, the man and shovel can dig my cellar" and "land and labor together produce the corn harvest." ${ }^{24}$ At all costs, the asymmetrical picture is avoided where persons use up materials and the services of the instrument to produce the outputs - thereby producing the "whole product" (see below) with its negative and positive components.

Long years of rigorous economic training are necessary in order to "forget" such an obvious difference between persons and things. The payoff from this rigorous indoctrination can be seen by investigating any economics textbook. Before the twentieth century, there was a darkness over the land and muddle-headed political economists like Thomas Hodgskin and other classical labourists had some sort of "labour theory" that tried to treat labour as having some "mysterious" attribute fundamentally different from the services of things. ${ }^{25}$ What could it be? Then around the turn of the twentieth century, a light burst over the land as the theory of marginal productivity emerged to solve the "problem of imputation." Every principles text, from Marshall's and Samuelson's to their vast contemporary progeny, discusses (and dismisses) the "labour theory" and presents marginal productivity theory.

The reader is invited to try to find a single economics text in the entire twentieth century which even mentions the simple fact that only human actions (labour services) are imputable - that responsibility must be imputed back through whichever instruments and tools to the human users. For a couple of decades, I have offered any fellow economist a free lunch if they find such a text, but to no avail. Failing that, one begins to appreciate the power of capitalist indoctrination in the "science" of economics.

One has to go back to the legally trained nineteenth-century Austrian economist, Friedrich von Wieser, to find any non-metaphorical mention of the R-word in the economics literature:

The judge ... who, in his narrowly-defined task, is only concerned with the legal imputation, confines himself to the discovery of the legally responsible factor, - that person, in fact, who is threatened with the legal punishment. On him will rightly be laid the whole burden of the consequences, although he could never by himself alone - without instruments and all the other conditions - have committed the crime. The imputation takes for granted physical causality ... If it is the moral imputation that is in question, then certainly no one but the labourer could be named. Land and capital have no merit that they bring forth fruit; they are dead tools in the hand of man; and the man is responsible for the use he makes of them. ${ }^{26}$ 


\section{David Ellerman}

There is a common pose that orthodox economists are scientifically judging the existing human rental system according to some normative principles such as Pareto optimality - analogous to the political economists, jurisprudents and philosophers in the antebellum American South who pretended to be judging their peculiar institution according to some moral principles and who unsurprisingly never supported any knockdown inalienable rights arguments against the institution. The social role of "economics" in our society based on human rentals suggests the opposite direction of causality. Normative principles are judged according to whether or not they align with the social role of orthodox economics in giving a "scientific account" of the existing or perhaps an idealised human rental system.

For instance, Wieser actually summarises the essentials of the labour theory of property (juridical imputation principle) critique of the employment system: "Land and capital have no merit that they bring forth fruit; they are dead tools in the hand of man; and the man is responsible for the use he makes of them." ${ }^{27}$ But that gives Wieser no second thoughts about the system of renting human beings; it only proves that the usual moral (factual) or legal notions of imputation obviously do not apply! Apparently, the usual moral/legal notions of imputation and responsibility apply to some other world than the world with which economists deal. It would be an economic reductio ad absurdum to apply the usual moral/legal notion of imputation to production since it conflicts with the liberty of renting human beings in the free market free enterprise system! The social role of economics in the human rental system demands a new notion of "economic imputation" in accordance with another new notion of economic responsibility: "In the division of the return from production, we have to deal similarly ... with an imputation, - save that it is from the economic, not the judicial point of view." 28 By defining "economic responsibility" in terms of the animistic version of marginal productivity, Wieser and later orthodox economists can finally draw the conclusion demanded by their professional vocation: to show that the competitive human rental system "economically" imputes the product in accordance with "economic" responsibility.

Thus we arrive at one of the high points of neoclassical microeconomics: trying to justify a metaphorical imputation of "distributive shares" in the product rights with a metaphorical notion of "responsibility." In contrast, the modern treatment of the labour theory of property (i.e. based on the juridical imputation principle) deals with the imputation of the "return from production" precisely from the moral, legal or "juridical point of view."

\section{The Fundamental Myth of Capitalist Property Rights}

The last ideological misconception that we can consider is about the structure of property rights in production. The labour theory of property is 
about the appropriation of newly produced property. The standard view pretends that no appropriation takes place in capitalist production since the right to the product is supposedly already part of the "private ownership of the means of production." Any appropriation, where the labour theory might be applied, could only be situated in some original state of nature when the first means of production were being appropriated, and in any case all that is lost in the mists of the past.

But the "story" is false from the beginning. The rights to the product are not part of the "ownership of the means of production" (private or otherwise); that is the fundamental myth sponsored by Marxist as well as orthodox economists. Appropriation does take place in normal production, not just in some original state of nature. Indeed, there is a market mechanism of appropriation quite unnoticed by conventional economics which buys the myth that the product is already part of the "ownership of the means of production."

Consider a technically defined production opportunity wherein people use some materials and a widget-maker machine to produce widgets. The "fundamental myth" is that the right to the product is part and parcel of the ownership of the capital good, the widget-maker machine. In this simple form, the myth is easy to defeat. Have labour hire capital or have some third party hire both. Then the hiring party would own the product, not the owner of the machine.

But that insight is much more "difficult" to grasp if we put the capital assets inside a corporate shell. Incorporate a company and have the owner of the widget-maker machine contribute it to the company in return for the only shares. Then he is the owner of the company and would "supposedly" be the owner of whatever is produced using the capital assets of the company (that is, the widget-maker machine). Isn't that what corporate ownership means? But that is again false for the same reasons. The machine can be rented out by the company. When the machine is rented out, then the company would not be the owner of the product produced using the company's capital assets (the machine). The company would only be an input-supplier to the "firm" or "enterprise" using the machine. Yet the original owner of the machine is still the owner of the company. This is a point about the structure of property rights, not marketplace power relations. The ownership of the product produced with a company's capital assets is not part and parcel of the ownership of the company. That is the fundamental myth about capitalist property rights.

It is the direction of the hiring contracts (who hires what or whom) that determines who bears the input-liabilities and who thus appropriates the output-assets - not the "ownership of the means of production." One party buys or already owns all the inputs to be used up in production and then, having absorbed those input-liabilities, can lay sole legal claim on the new produced assets.

The idea that the product was part of the "ownership of the means of production" was crystallised by Marx and thus he named the system 


\section{0}

"capitalism." It is a misnomer. The product rights are not part of capital. Both Marxists (and by virtue most council theorists) and the defenders of "capitalism" agreed on the myth that the owner of capital was the "owner of the firm"; they agreed to disagree on whether that "owner" should be public or private - so that the Cold War was much like a modern version of the Peloponnesian War between the Athenians who had privately owned slaves and the Spartans who had publicly owned slaves.

\section{The Case for Workplace Democracy}

\section{The Labour Theory of Property}

We are now in a position to briefly state the case for the democratic firm based on ordinary jurisprudence. I will state the case based on the "labour theory of property" - which is just the ordinary juridical principle of assigning legal responsibility in accordance with de facto or factual responsibility.

Regardless of the productivity of the instruments and materials of production, only the human beings involved in the firm can be de facto responsible for producing the product. But hordes of textbook-trained economists immediately throw up their hands and point out that you can't impute the entire output to labour ("labour" = "managers and workers"); the product must be divided to account for the income to the other inputs! But they are wrong; they just think too positively. They must learn to think negatively. There is also a negative product. Labour does not produce the product ex nihilo; labour produces the product by using up the input materials and the services of the capital instruments. And thus labour is also de facto responsible for that negative product (and the satisfaction of those inputliabilities accounts for the other factor incomes). The positive and negative product, the (undivided) produced assets and input-liabilities, make what we might call the whole product.$^{29} \mathrm{It}$ is not described by a number but by an ordered list of positive and negative numbers, a "vector."

The imputation principle (assign the legal responsibility to the de facto responsible party) implies that labour should have the legal responsibility for the positive and negative fruits of their labour. In the nineteenth century, Hodgskin and others asserted "Labour's Right to the Whole Product." 30 Labour should be legally liable for the used-up inputs and should legally own the produced outputs; labour should be the firm. The net value of whole product is the "residual," so the responsibility argument concludes that labour ought to be the residual claimant.

\section{The Analogous Case for Abolishing the Coverture Marriage Contract}

Historical examples of voluntary contracts that have been abolished due to the abolitionist, democratic and feminist movements are, respectively, 
the voluntary slavery contract, the non-democratic political constitution (pactum subjectionis) and the coverture marriage contract. Since the coverture contract is the most recent example, it may be useful to review the inalienable rights argument against that free and voluntary contract. Note that we are not playing the usual left-wing parlour game of escalating one's notion of "voluntariness" until the contract we want to rule out is seen as being "involuntary." The inalienable rights critique applies even if it is perfectly voluntary.

Normally, to establish a legal guardian relationship of one adult as guardian over another adult as dependant, there must be some factual condition on the part of the dependant such as some mental disability, insanity or senility that needs to be certified. Yet the coverture marriage contract established the husband as the "Lord and Baron" or, in less flowery language, guardian over the feme covert who had no independent legal personality and thus could not make contracts or own property except in the name of the husband:

By marriage, the husband and wife are one person in law: that is, the
very being or legal existence of the woman is suspended during the
marriage, or at least is incorporated and consolidated into that of
the husband; under whose wing, protection, and cover, she performs
everything; and is therefore called in our law-French, a feme covert,
and is said to be under the protection and influence of her husband,
her baron, or lord; and her condition during her marriage is called her
coverture. $^{31}$

In an adult woman of normal capacity, that factual capacity is factually inalienable in the sense that the woman cannot by voluntary agreement actually alienate that capacity and factually become a person of diminished capacity, a dependant, factually suitable for a guardianship relation. Yet the coverture contract gave her precisely that legal position (note that the point is the contrast between the factual and the legal situation). Since the woman is just as much a de facto capacitated adult as before voluntarily agreeing to the contract, the coverture contract was essentially an institutional fraud sponsored by the legal system in a patriarchal society that allowed the reduction of married women to the status of legal dependants to parade in the form of a voluntary contract. The critique of the human rental or employment contract is entirely analogous using the usual notions of factual and legal responsibility as applied to the appropriation of the liabilities and assets created in production.

\section{The Case for Abolishing the Human Rental Contract}

The inalienable rights argument against not only buying but renting people can be illustrated with a simple story. Suppose that an entrepreneur hired 


\section{2}

an employee for general services (no intimations of criminal intent). The entrepreneur similarly hired a van, and the owner of the van was not otherwise involved in the entrepreneur's activities. Eventually the entrepreneur decided to use the factor services he had purchased (man-hours and van-hours) to rob a bank. After being caught, the entrepreneur and the employee were charged with the crime. In court, the worker argued that he was just as innocent as the van owner. Both had sold the services of factors they owned to the entrepreneur. "Labor Service is a Commodity." 32 The use the entrepreneur makes of these commodities is his own business.

The judge would, no doubt, be unmoved by these arguments. The judge would point out it was plausible that the van owner was not responsible. He had given up and transferred the use of his van to the entrepreneur, so unless the van owner was otherwise personally involved, his absentee ownership of the factor would not give him any responsibility for the results of the enterprise. But man-hours are a peculiar commodity in comparison with van-hours. The worker cannot "give up and transfer" the use of his own person, as the van owner can the van. Employment contract or not, the worker remained a fully responsible agent knowingly co-operating with the entrepreneur. The employee and the employer share the de facto responsibility for the results of their joint activity, and the law will impute legal responsibility accordingly:

All who participate in a crime with a guilty intent are liable to punishment. A master and servant who so participate in a crime are liable criminally, not because they are master and servant, but because they jointly carried out a criminal venture and are both criminous. ${ }^{33}$

Unless one wants to argue that employees suddenly become robots or some sort of non-responsible instruments to be "employed" by the "employer" when the venture "they jointly carried out" was non-criminal, then the employees (and working employer) in an enterprise are jointly factually responsible for using up the inputs (i.e. creating the input-liabilities) and producing the products (i.e. the output-assets) that make up the negative and positive components in the "whole product" representing the whole results in a productive opportunity.

Thus, by the usual juridical norm of imputation, they should jointly have the legal liabilities for using up the inputs and the legal ownership of the produced outputs. Yet, the employees, qua employees, have 0 per cent of the input-liabilities charged against them and 0 per cent of the produced outputs owned by them, which is exactly the legal role of a rented nonresponsible instrument. Anyone who can tell the difference between 0 per cent and 100 per cent can see that the whole "distributive shares" in the product are only metaphorical property rights. The employer holds 100 per cent of the input-liabilities and owns 100 per cent of the produced outputs. Yet the employees are as inextricably and inalienably co-responsible (in 
factual terms) as in the case of the criminal venture. That is (one form of) the inalienable rights argument that descends from the Reformation (where it took the form of the "inalienability of conscience") and the Enlightenment.

The employees cannot by any voluntary act turn themselves into de facto non-responsible instruments, just as the married woman cannot voluntarily alienate her adult capacity to become a de facto dependant. The whole contract to rent human beings is another institutional fraud legally sponsored by a society based on renting (instead of owning) other humans so that the positive and negative fruits of the rented people can be appropriated by the employer. Thus the neo-abolitionist claim that the employer-employee contract for the renting of human beings is inherently invalid. ${ }^{34}$

Generalising from these two cases, one can see the general form of the inalienability argument against personal alienation contracts. Any contract that puts a normally capacitated person in the legal position of a person of diminished capacity or non-capacity cannot actually be voluntarily fulfilled to factually justify that legal role. The person remains a person. Hence the legal authorities always must have an alternative factual performance that will legally count as "fulfilling" the contract, and that factual performance always has the same form: obey your master, obey your ruler, obey your husband or obey your employer. The resulting legal contract is only an institutionalised fraud parading on the stage as a voluntary contract (i.e. with voluntary obedience) to allow the "legalised" treatment of normal persons as having only diminished or no capacity.

Unlike the coverture marriage contract, the human rental contract is still legally valid. Perhaps 100 or even 50 years from now, today's good-hearted orthodox economists, lawyers, political scientists and liberal intellectuals will be looked back upon and asked in absentia: "Just which part of renting human beings didn't you understand?"

Notice that this argument is entirely independent of the size of the wage or quality of working conditions, and has no connection to any theory of price or value including any so-called "labour theory of value." 35 The parallel argument from democratic theory arrives at the same conclusion about the employment contract except that it is then viewed as the private Hobbesian pactum subjectionis of the workplace. The fact that a whole economic civilisation is founded on a bogus "contract" (the contract to rent human beings) to transfer what is untransferable is "unbelievable" to most people - which is why so much false consciousness needs to be socially constructed to sustain the system. While the earlier systems of legalised violations of human rights had their platoons of intellectual mercenaries, no previous system had anything approaching the sophistication of orthodox economics, political science, legal theory and the other social sciences. 


\section{Justice and Injustice}

Whenever two things ought to match, like being a legal and factual dependant or being legally and factually responsible for something, then there are two ways to have a mismatch - like the type I and type II errors in statistics. It is an injustice when there is a mismatch. For instance, when a factually guilty person is judged legally not guilty, that is a miscarriage of justice - analogous to a type I error of rejecting a true hypothesis. Or when a factually innocent person is found to be legally guilty, that is also a miscarriage of justice - like the type II error of accepting a false hypothesis.

In the case at hand, both errors occur. The factually responsible party or association, the people working within a firm, do not get the legal responsibility for the whole product, and the party or association that does get the legal responsibility, such as the corporate shareholders in the employing corporation, do not have the factual responsibility. In a remarkable case of courage and clarity, the British Conservative minister and writer, Lord Eustace Percy, precisely pointed this out in 1944:

Here is the most urgent challenge to political invention ever offered to the jurist and the statesman. The human association which in fact produces and distributes wealth, the association of workmen, managers, technicians and directors, is not an association recognised by the law. The association which the law does recognise - the association of shareholders, creditors and directors - is incapable of production and is not expected by the law to perform these functions. We have to give law to the real association, and to withdraw meaningless privilege from the imaginary one. ${ }^{36}$

\section{Conclusion}

The workers' councils of the European council movements can be seen as the self-conscious eruption in history of what Percy called the "human association which in fact produces and distributes wealth, the association of workmen, managers, technicians and directors." ${ }^{37}$

"For many, the workers councils became a viable alternative to the capitalist economic system and the established political order, the cells of a future self-managed society." ${ }^{38}$ Yet no matter how attractive the direct action and general strike strategies have been to express left-wing enthusiasms and being-against-the-system posturing, they have hardly proved successful as a shortcut through history. Particularly now in the twenty-first century, after the collapse of much of the Left in the late twentieth century, there seems to be no real alternative to Rudi Dutschke's "long march through the institutions of power." This includes refounding the intellectual case of workplace democracy - our task here - in a way quite distinct from and for 
the most part antithetical to Marxist theory, not to mention "real-existing Marxist socialism." 39

\section{Notes}

1 Ralf Hoffrogge, Working Class Politics in the German Revolution, 111.

2 Henry Maine, Ancient Law, 100.

3 Frank Knight, Freedom and Reform, 27, fn. 4.

4 John Locke, Two Treatises on Government, Second Treatise, \$24.

5 Baron de Montesquieu, The Spirit of the Laws, Vol. I, Bk. XV, Ch. V.

6 William Blackstone, Ehrlich's Blackstone, section on "Master and Servant."

7 Samuel Seabury, American Slavery Justified by the Law of Nature.

8 Eric McKitrick, Slavery Defended.

9 Drew Faust, The Ideology of Slavery.

10 Paul Finkelman (ed.), Defending Slavery.

11 On the Scholastics, see Richard Tuck, Natural Rights Theories.

12 Edward Bryan, Letters to the Southern People, 10 (italics in original); partly quoted in J. Philmore, "The Libertarian Case for Slavery," 43.

13 James Mill, Elements of Political Economy, ch. I, section II.

14 Carl Christ, "The Competitive Market and Optimal Allocative Efficiency," 334; quoted in Philmore, "The Libertarian Case for Slavery," 52.

15 Otto von Gierke, Political Theories of the Middle Age.

16 Brian Tierney, The Idea of Natural Rights, 182.

17 Robert Nozick, Anarchy, State, and Utopia, 15, 113.

18 Edward S. Corwin, The "Higher Law" Background of American Constitutional Law, 4.

19 Ernst Cassirer, The Myth of the State, 175.

20 Philmore, "The Libertarian Case for Slavery," 55.

21 Stanley Engerman, "Some Considerations Relating to Property Rights in Man," 43-65.

22 Paul A. Samuelson, Economics, 52, italics in original.

23 David Begg et al., Economics, 201.

24 Samuelson, Economics, 536-7.

25 Hodgskin, The Natural and Artificial Right of Property Contrasted.

26 Friedrich von Wieser, Natural Value, 76-9.

27 Ibid.

28 Ibid., 76.

29 In the neoclassical literature, this standard vector is called the "input-output vector" as in James Quirk and Rubin Saposnik, Introduction to General Equilibrium Theory and Welfare Economics, 27; or "production vector" or just "production."

30 Anton Menger, The Right to the Whole Produce of Labour. See also David Ellerman, Property \& Contract in Economics; David Ellerman, "The Labour Theory of Property and Marginal Productivity Theory"; David Ellerman, "On the Labor Theory of Property"

31 Blackstone, Ehrlich's Blackstone.

32 Armen Alchian and William R. Allen, Exchange and Production, 469.

33 Francis Batt, The Law of Master and Servant, 612. 


\section{6}

34 David Ellerman, "On the Renting of Persons."

35 David Ellerman, "Marxism as a Capitalist Tool."

36 Eustace Percy, The Unknown State, 38.

37 Ibid.

38 Comack, Wild Socialism, 75.

39 There is also the task of rethinking the legal structure of the self-managed democratic firm to avoid the problems of the hybrid "socialist" firms in the only previous historical example of a country attempting to be politically and economically self-managed, the Socialist Federal Republic of Yugoslavia. See David Ellerman, The Democratic Worker-Owned Firm.

\section{References}

Alchian, Armen and William R. Allen. Exchange and Production: Theory in Use. Belmont, CA: Wadsworth, 1969.

Batt, Francis. The Law of Master and Servant. 5th edn. London: Pitman, 1967.

Begg, David, Stanley Fischer and Rudiger Dornbusch. Economics. 5th edn. London: McGraw-Hill Co., 1997.

Blackstone, William. Ehrlich's Blackstone. Edited by J. W. Ehrlich. New York: Capricorn Books, 1959.

Bryan, Edward B. Letters to the Southern People. Charleston, SC: Walker, Evans \& Co., 1858.

Cassirer, Ernst. The Myth of the State. New Haven, CT: Yale University Press, 1963.

Christ, Carl F. "The Competitive Market and Optimal Allocative Efficiency." In Competing Philosophies in American Political Economics. Edited by John Elliott and John Cownie. 332-8. Pacific Palisades, CA: Goodyear, 1975.

Comack, Martin. Wild Socialism: Workers Councils in Revolutionary Berlin 191821. Lanham, MD: University Press of America, 2012.

Corwin, Edward S. The "Higher Law" Background of American Constitutional Law. Ithaca, NY: Cornell University Press, 1955.

Ellerman, David. The Democratic Worker-Owned Firm. London: Unwin-Hyman Academic, 1990. Accessed at www.ellerman.org.

- "On the Labor Theory of Property: Is the Problem Distribution or Predistribution?" Challenge: The Magazine of Economic Affairs 60, no. 2 (2017): 171-88.

- "The Labour Theory of Property and Marginal Productivity Theory." Economic Thought 5, no. 1 (2016): 19-36.

- "Marxism as a Capitalist Tool." Journal of Socio-Economics 39, no. 6 (December 2010): 696-700.

C Property \& Contract in Economics: The Case for Economic Democracy. Cambridge, MA: Blackwell, 1993.

—. "On the Renting of Persons: The Neo-Abolitionist Case Against Today's Peculiar Institution.” Economic Thought 4, no. 1 (2015): 1-20.

Engerman, Stanley. "Some Considerations Relating to Property Rights in Man." Journal of Economic History 33, no. 1 (1973): 43-65.

Faust, Drew Gilpin (ed.). The Ideology of Slavery: Proslavery Thought in the Antebellum South, 1830-1860. Baton Rouge, LA: Louisiana State University Press, 1981. 
Finkelman, Paul (ed.). Defending Slavery: Proslavery Thought in the Old SouthA Brief History with Documents. Boston, MA: Bedford/St. Martin's, 2003.

Gierke, Otto von. Political Theories of the Middle Age. Translated by F. W. Maitland. Boston, MA: Beacon Press, 1958.

Hodgskin, Thomas. The Natural and Artificial Right of Property Contrasted. Clifton, NJ: Augustus M. Kelley, 1973 [1832].

Hoffrogge, Ralf. Working Class Politics in the German Revolution: Richard Müller, the Revolutionary Shop Stewards and the Origins of the Council Movement. Translated by Joseph B. Keady. Leiden: Brill, 2015.

Knight, Frank. Freedom and Reform. New York: Harper \& Row, 1947.

Locke, John. Two Treatises on Government. New York: New American Library, 1960 [1690].

McKitrick, Eric. Slavery Defended: The Views of the Old South. Englewood Cliffs, NJ: Prentice-Hall, 1963.

Maine, Henry. Ancient Law. London: Dent, 1972.

Menger, Anton. The Right to the Whole Produce of Labour: The Origin and Development of the Theory of Labour's Claim to the Whole Product of Industry. Translated by M. E. Tanner. New York: Augustus M. Kelley, 1970 [1899].

Mill, James. Elements of Political Economy. 3rd edn. London: Baldwin, Cradock, and Joy, 1826.

Montesquieu, Baron de. The Spirit of the Laws. Translated by Thomas Nugent. New York: Appleton, 1912 [1748].

Nozick, Robert. Anarchy, State, and Utopia. New York: Basic Books, 1974.

Pannekoek, Anton. Workers' Councils. Edited by Robert F. Barsky. Oakland, CA: AK Press, 2003.

Percy, Eustace. The Unknown State: 16th Riddell Memorial Lectures. London: Oxford University Press, 1944.

Philmore, J. "The Libertarian Case for Slavery: A Note on Nozick." Philosophical Forum 14 (1982): 43-58.

Quirk, James and Rubin Saposnik. Introduction to General Equilibrium Theory and Welfare Economics. New York: McGraw-Hill, 1968.

Samuelson, Paul A. Economics. 10th edn. New York: McGraw-Hill, 1976.

Seabury, Samuel. American Slavery Justified by the Law of Nature. Miami, FL: Mnemosyne Publishing Company, 1969.

Tierney, Brian. The Idea of Natural Rights: Studies on Natural Rights, Natural Law, and Church Law 1150-1625. Grand Rapids, MI: William B. Eerdmans Publishing, 1997.

Tuck, Richard. Natural Rights Theories. Cambridge: Cambridge University Press, 1979.

Wieser, Friedrich von. Natural Value. Translated by C. A. Malloch. New York: G. E. Stechert and Company, 1930 [1889]. 